http://kitaibelia.unideb.hu/

ISSN 2064-4507 (Online) • ISSN 1219-9672 (Print)

(C) 2015, Department of Botany, University of Debrecen, Hungary

20 (2): 202-205.; 2015

DOI: $10.17542 /$ kit.20.202

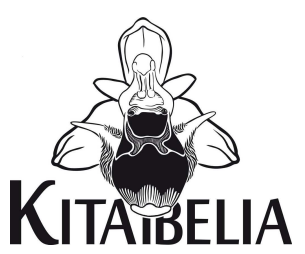

\title{
A veszélyeztetett Anacamptodon splachnoides (Froel. ex Brid.) Brid. új adata a Bükk-hegységből
}

SzÚCS Péter ${ }^{1 *}$, JózSEF Júlia², PAPP Viktor Gábor ${ }^{3}$ \& KuTSZEGI Gergely

(1) Eszterházy Károly Főiskola TTK Biológiai Intézet, Növénytani és Ökológiai Tanszék; H-3300 Eger, Leányka utca 6.; *szucs.peter@ektf.hu

(2) Szent István Egyetem, H-2100, Gödöllő, Páter Károly utca 1.

(3) Bükki Nemzeti Park Igazgatóság, H-3304 Eger, Sánc u. 6.

(4) Magyar Tudományos Akadémia ÖK Ökológiai és Botanikai Intézet, H-2163, Vácrátót, Alkotmány utca 2-4.

\section{A new record of the threatened Anacamptodon splachnoides (Froel. ex Brid.) Brid. from the Bükk Mts. (NE Hungary)}

\begin{abstract}
A new locality of the moss species Anacamptodon splachnoides (Froel. ex Brid.) Brid. was discovered in a Turkey oak-dominated forest stand in the Bükk Mts. (near Varbó village, North Hungarian Montains). A small population of this threatened bryophyte was found in a wet root-hole of a living Quercus cerris L. tree.
\end{abstract}

Keywords: Amblystegiaceae, Bükk Mts., dendrotelm, knot-hole moss, North Hungarian Montains, Quercus cerris

Összefoglalás - A szerzők a veszélyeztetett Anacamptodon splachnoides (Froel. ex Brid.) Brid. mohafaj új adatát közlik a Bükk-hegységből, egy Varbó község melletti cseres-kocsánytalan tölgyesből. E veszélyeztetett lombosmohafaj kis populációját egy élő Quercus cerris fa gyökfőjének üregében azonosították.

Kulcsszavak: Amblystegiaceae, Bükk-hegység, dendrotelma, Északi-középhegység, ritka mohafaj, Quercus cerris

\section{Bevezetés}

Az európai szinten veszélyeztetett (ECCB 1995, HoDGETs 2015), hazánkban természetvédelmi oltalom alatt álló (ANONYM 2012) Anacamptodon splachnoides (Froel. ex Brid.) Brid. lombosmoha faj sajátos előfordulási körülményeiről, veszélyeztetettségi és védettségi helyzetéről, taxonómiájáról, valamint korábbi előfordulásairól NÉMETH \& ERZBERGER (2015) munkája ad átfogó hazai és nemzetközi áttekintést. Az elmúlt évek intenzívebb hazai mohaflorisztikai és térképezési munkái, valamint a célzott terepi vizsgálatok eredményeként NÉMETH \& ERZBERGER (2015) a szóban forgó mohafaj 27 kolóniáját azonosította. Gyűjtéseik főleg a Magyar-középhegység területéről, minden esetben csertölgy (Quercus cerris L.) talajfelszínhez közeli, nedves üregeiből származnak. A lelőhelyek közül három a Börzsönyben, kettő a Vértesben, kettő a Gerecsében, 20 pedig a Balaton-felvidéken található. Jelen közlemény az A. splachnoides újonnan felfedezett bükki élőhelyének leírását ismerteti. 


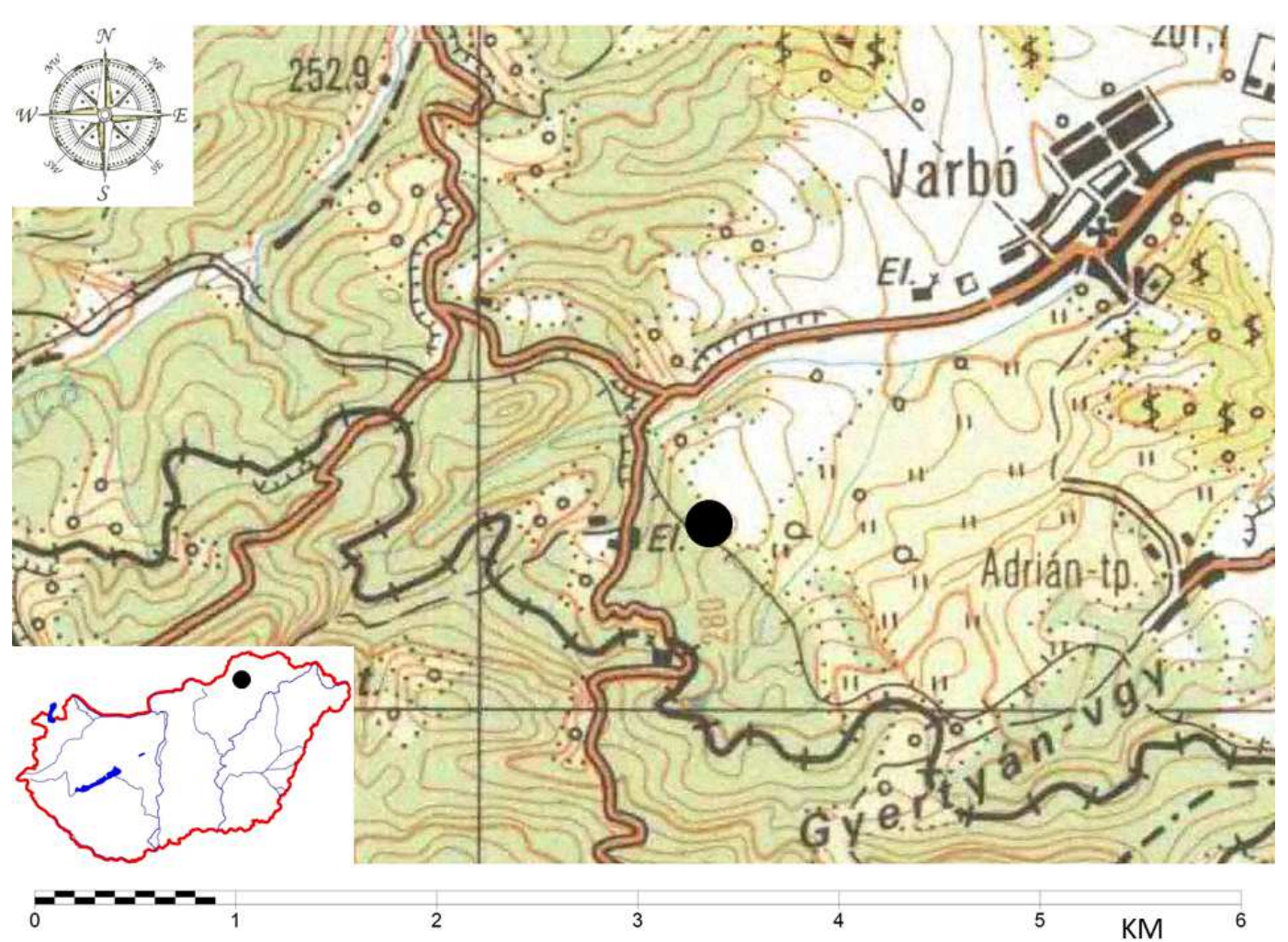

1. ábra. Az Anacamptodon splachnoides (Froel. ex Brid.) Brid. előfordulása Varbó község mellett.

Fig. 1. The occurrence of Anacamptodon splachnoides (Froel. ex Brid.) Brid. near Varbó village.

\section{Anyag és módszer}

A terepi felvételezés 2014 októberében és 2015 júliusában zajlott. A lelőhely koordinátáit GPS-készülékkel rögzítettük. A taxon azonosításához CZERNYADJEVA (2007) határozókulcsát használtuk. A mohák megnevezésénél PAPP et al. (2010) munkáját vettük alapul, míg az edényes növények esetében KIRÁLY (2009) határozókönyvéhez igazodtunk. A begyűjtött bizonyító herbáriumi példányokat a Magyar Természettudományi Múzeum Növénytárában (BP), illetve az Eszterházy Károly Főiskola Növénytani és Ökológiai Tanszékének Kriptogám Herbáriumában (EGR) helyeztük el.

\section{Eredmények}

A terepi felvételezés során az Anacamptodon splachnoides fajt sporofitonos állapotban figyeltük meg; felfedezett populációjának nagysága megközelítőleg $100 \mathrm{~cm}^{2}$ volt. Gyepje egy közel 50 éves, sarjeredetű Quercus cerris (mellmagassági törzsátmérő kb. $25 \mathrm{~cm}$ ) gyökfőjén kialakult kisebb odú nedves nyílásánál jelent meg (2. ábra A). Az A. splachnoides közvetlen környezetében előforduló, egyéb mohafajok: Hypnum cupressiforme Hedw., Platygyrium repens (Brid.) Schimp. és Brachythecium rutabulum (Hedw.) Schimp. A mintavételezési protokoll (ÓDOR 2015) szerint vizsgált, 17,8 m sugarú, $1000 \mathrm{~m}^{2}$-es körön belül kimutatott egyéb kéreg- és korhadéklakó mohafajok: Amblystegium serpens (Hedw.) Schimp., Dicranum montanum Hedw., D. tauricum Sapjegin, Orthotrichum stramineum Hornsch. ex Brid. 
Lelőhelyi adatok és élőhelyjellemzés

Borsod-Abaúj-Zemplén megye; Varbó; Fónagyság („Varbó 20/J” erdőrészlet) mellett, az erdészeti épületektől kb. 350 m-re keletre, dombtetőn, cseres-kocsánytalan tölgyesben, élő Quercus cerris gyökfőjén (2. ábra A), N 48.14929, E 20.59445², 290 m, 2014. 10. 25. leg. Kutszegi G., József J., det.: Szűcs P., conf.: Németh Cs. [7889.2].

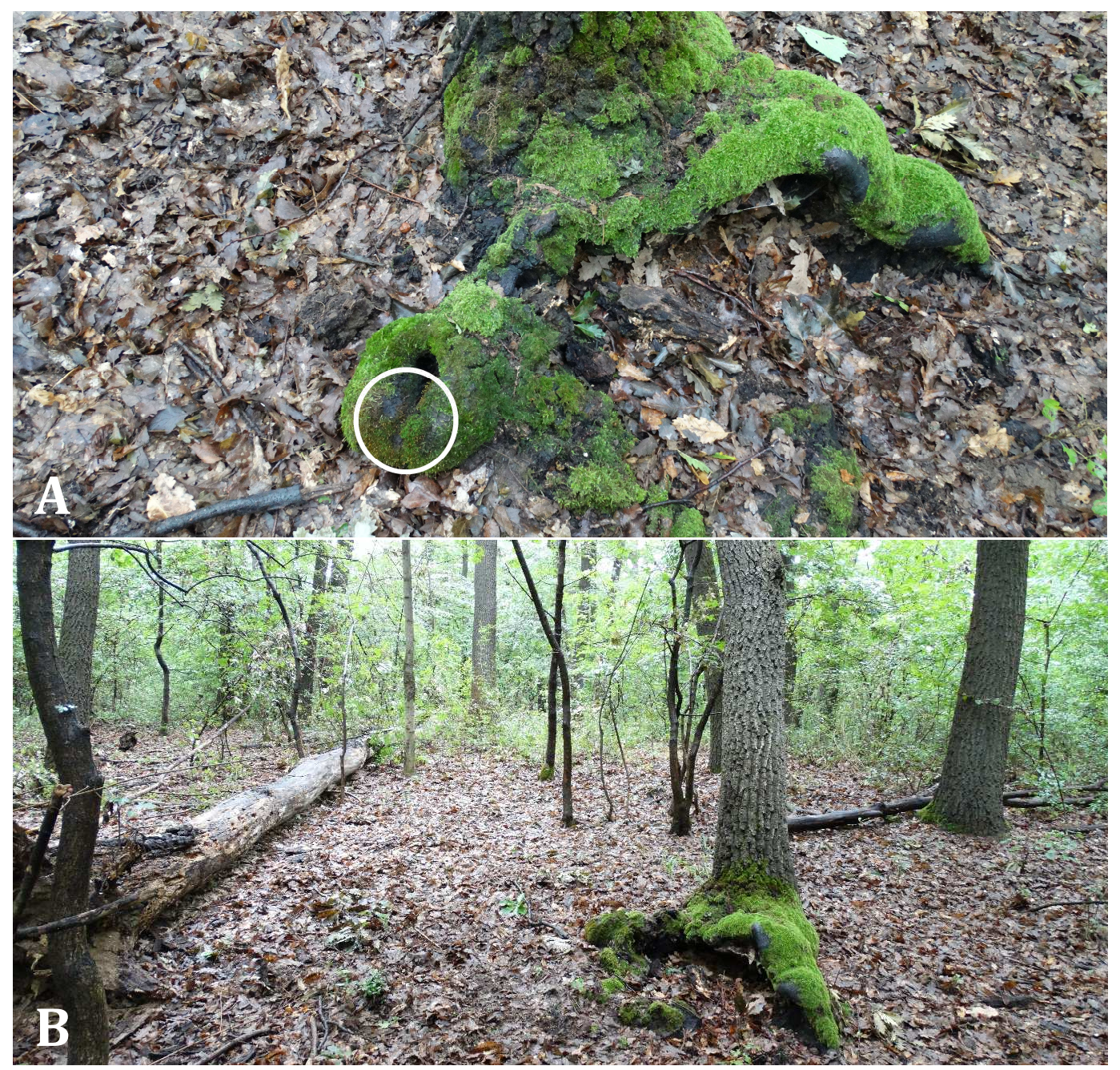

2. ábra. Az A. splachnoides varbói populációja egy Q. cerris faegyed gyökfőjének nedves üregében (A). A környezet, előtérben a moha élőhelyéül szolgáló Q. cerris egyeddel (B) (Papp Viktor Gábor felvételei). Fig. 2. The population of $A$. splachnoides in a wet root-hole of a Q. cerris tree near Varbó (A). The habitat with the host Q. cerris individual in the foreground (B) (photo by Gábor Viktor Papp).

Az A. splachnoides új bükki populációjának otthont adó sarjaztatott, 85 éves (ÓDoR 2015) cseres-kocsánytalan tölgyes erdőállomány (2. ábra B) fó állományalkotó fafajai a Quercus cerris L., a Q. petraea (Matt.) Liebl. és az Acer campestre L. Elegyfafajai: Carpinus betulus L., Ulmus glabra Huds., Fraxinus excelsior L., Pyrus pyraster (L.) Burgsd. A cserjeszintben Crataegus monogyna Jacq., Cornus mas L. és Ligustrum vulgare L. található. A lágyszárúak szintjében gyéren Galium odoratum (L.) Scop. és Elymus sp. volt megfigyelhető. A 17,8 m sugarú (1000 m²es) vizsgálati területen megmért teljes holtfatérfogat $41 \mathrm{~m}^{3} /$ ha volt, melyből az álló holtfa 
tömeg-aránya 26\%-nak adódott. A mintaterület élőfa-készlethez viszonyított holtfatérfogata 8\% (ÓDOR 2015).

\section{Konklúzió}

Az újabb börzsönyi lelőhelyektől eltekintve az Anacamptodon splachnoides mohafaj eddig kizárólag 1979 előtti adatait ismertük az Északi-középhegység területéről (NÉMETH \& ERZBERGER 2015). A faj utóbbi években - fóként a célzott florisztikai kutatások eredményeként - előkerült hazai populációi arra engednek következtetni, hogy további tematikus kereséssel hegy- és dombvidéki tölgyeseinkben másutt is nagy eséllyel bukkanhatunk rá újabb, kis kiterjedésű gyepjeire.

\section{Köszönetnyilvánítás}

Köszönettel tartozunk Horváth Adriennek a térkép készítésében nyújtott segítségéért, valamint a kézirat lektorainak munkájukért és értékes javaslataikért. A kutatás a „Fenntartható természetvédelem megalapozása magyarországi Natura 2000 területeken” címú Svájci-Magyar Együttmúködési Program (SH/4/8) keretében valósult meg. A közlemény a Társadalmi Megújulás Operatív Program Kutatás, Innováció, Együttmüködések Társadalmi innováció és kutatási hálózatok együttmüködésének erősítése az Eszterházy Károly Főiskola, a Bay Zoltán Alkalmazott Kutatási Nonprofit Kft. és az Agria TISZK Közhasznú Nonprofit Kft. együttmúködésével címet viselő, TÁMOP-4.2.1.D-15/1/KONV-2015-0013 azonosítószámú projekt keretében készült, ami az Európai Unió támogatásával és az Európai Szociális Alap társfinanszírozásával valósult meg.

\section{Irodalom}

ANonym (2012): A vidékfejlesztési miniszter 100/2012. (IX. 28.) VM rendelete a védett és a fokozottan védett növény- és állatfajokról, a fokozottan védett barlangok köréről, valamint az Európai Közösségben természetvédelmi szempontból jelentős növény- és állatfajok közzétételérooll szóló 13/2001. (V. 9.) KöM rendelet és a növényvédelmi tevékenységről szóló 43/2010. (IV. 23.) FVM rendelet módosításáról [ministerial order concerning protection of nature]. - Magyar Közlöny 128: 20903-21019.

ECCB (1995): Red data book of European bryophytes. - European Committee for the Conservation of Bryophytes, Trondheim, $291 \mathrm{pp}$.

Czernyadjeva I. V. (2007): The genus Anacamptodon (Amblystegiaceae, Bryophyta) in Russia and Transcaucasia. - Arctoa 16: 1-6.

HoDGETTS N. G. (2015): Checklist and country status of European bryophytes - towards a new Red List for Europe. - Irish Wildlife Manuals, No. 84. National Parks and Wildlife Service, Department of Arts, Heritage and the Gaeltacht, Ireland.

KIRÁLY G. (szerk.) (2009): Új magyar füvészkönyv. Magyarország hajtásos növényei. Határozókulcsok. ANPI, Jósvafő, 616 pp.

NÉmeTH CS. \& ERZBERGER P. (2015): Anacamptodon splachnoides (Amblystegiaceae): Hungarian populations of a moss species with a peculiar habitat. - Studia botanica hungarica 46: 61-75.

ÓDOR P. (2015): A korhadó faanyag viszonyai és biodiverzitásban betöltött szerepe az Észeki-középhegy-ségben. - MTA ÖK, interneten közzétéve. http://holtfa.okologia.mta.hu/node/9 (Hozzáférés: 2015. 08. 22.)

PAPp B., ERZBERGer P., ÓDOR P., Hock Zs., SZövÉNyi P., SZURDoKi E. \& Tóth Z. (2010): Updated checklist and red list of Hungarian bryophytes. - Studia botanica hungarica 41: 31-59.

Beérkezett / received: 2015. 09. 01. • Elfogadva / accepted: 2015. 09. 04. 